\title{
Characterization and Recycling of Organic Waste after Co-Composting
} - A Review

\author{
Z. Anwar ${ }^{1}$, M. $\operatorname{Irshad}^{1}$, I. Fareed ${ }^{2} \&$ A. Saleem ${ }^{1}$ \\ ${ }^{1}$ Department of Environmental Sciences, COMSATS Institute of Information Technology, Abbottabad, Pakistan \\ ${ }^{2}$ Resources Engineering and Management, University of Kurdistan, Hewler, Iraq \\ Correspondence: Z. Anwar, Department of Environmental Sciences, COMSATS Institute of Information \\ Technology, Abbottabad, Pakistan. E-mail: zobiaanwar@ciit.net.pk
}

Received: December 9, 2014 Accepted: January 28, 2015 Online Published: March 15, 2015

doi:10.5539/jas.v7n4p68

URL: http://dx.doi.org/10.5539/jas.v7n4p68

\begin{abstract}
Co-composting produces a valuable compost material that can be used as valuable soil amendment. The process of the co-composting and control of the composting factors are the current challenges for the researchers. There are different factors that govern the quality, stability and the maturity of the co-compost in terms of amount of plant nutrients and reduction of heavy metals. Among these, $\mathrm{C}: \mathrm{N}$ ratio is a parameter that can affect the loss of plant nutrients. Different studies showed wide ranges of C:N ratios (14-40) for maturity of quality compost. Temperature, aeration and types of the bulking agents also regulate the process of co-composting. Most widely used co-composted materials are animal manures with agro-wastes (sawdust, wheat straw, rice straw, corn stalks etc.). This practice brought substantial loss of heavy metals and maximum retention of plant nutrients. Higher nutrients contents of the compost and favourable soil properties as a result of co-composting of the saw dust, cow dung and egg shells have been reported. The application of co-composted dairy manure with wheat straw and sawdust produced higher plant biomass. Co-compost of cattle manure with rice straw produced an organic matter, total $\mathrm{N}$ and $\mathrm{C}: \mathrm{N}$ ratio contents suitable for soil amendment. Therefore, this review focuses on the characteristics and utilization of organic waste after a reasonable co-composting process.
\end{abstract}

Keywords: co-composting, livestock manures, sewage sludge, nutrient transformation, chemical characterization

\section{Introduction}

Cattle farms are producing a huge amount of manure throughout the world which must be managed through proper disposal practices to avoid the adverse impacts on environment (Burton \& Turner, 2003). This has become a significant management problem in several countries. The issue of waste management is increasing due to the current environmental awareness. It has stimulated the researchers to identify economically feasible and environmental friendly technologies for animal manure to be used as a source of soil fertilizer (Zhang \& He, 2006). Composting is microbial based aerobic process considered to be an environmentally sound way to minimize organic waste and produce organic fertilizer or soil conditioner (Gajdos, 1992). The process is able to transform unstable organic waste (such as sewage sludge, municipal solid waste, tannery waste, animal manure, poultry manure etc) into stable ones by converting them into a humus like structure called compost which results into a valuable agronomic by-product (Kashmanian et al., 2000).

Composting presents a low-technology and low-investment process to add value to organic solid waste through conversion into an organic fertilizer known as compost (Neves et al., 2009). It also considerably reduces odour emissions, biodegradable hydrocarbons, and dries up the waste making it unattractive to insects (Barrington et al., 2002). Co-composting is an important bio-waste treatment for achieving sustainable process and zero waste. Waste co-composting also enhances the compost quality by the comprehensive usage of diversified material properties (Fang \& Wong, 1999). This type of waste management is well accepted when compared with other types, such as incineration or landfill. Certain physical and chemical characteristics of animals manure are not adequate for composting and may limit the efficiency of composting process. Several modifications in the process of composting has been suggested such as the addition of biodegradable waste, bulking agents etc to reach the optimal C:N ratio, degradation rate and compost quality (Herwijnen et al., 2007). The selection of appropriate bulking agent would modify manure composting substrate properties (moisture, porosity, C:N ratio, 
pH) (Petric et al., 2009).

The performance of the co-composting process and the quality of the end-product (the compost) are governed by the composition of the waste material, bulking agents and the management strategies. Composting and co-composting are among the few natural process available for the disposal of solid pollution combined with resource regeneration via stabilizing different types of organic waste. Co-composting has received increasing interest as a method of handling various types of livestock manures (Ogunwande et al., 2008) and presented a low investment technology. As in the most production processes, the implementation of large-scale composting brings greater economic benefits. Co-composting of more than one type of waste can be a more sustainable management process of solid waste (Neves et al., 2009). The addition of a bulking agent for composting optimizes substrate properties such as air space, moisture content, $\mathrm{C}: \mathrm{N}$ ratio, particle density, $\mathrm{pH}$ and mechanical structure, affecting positively the decomposition rate (Neves et al., 2009).

The majority of research studies have mainly focused on monitoring the influence of bulking agent types on the composting of manure (Petric et al., 2009), but the research articles describing the effect of bulking agents on the physico-chemical characteristics of composting manures are deficient. Therefore, efforts have been made to review the co-composting of different materials and its effects on plant nutrient transformations under varied conditions.

\section{Factors Affecting Co-Composting}

Compost maturity depends on several factors such as characteristics of initial wastes $(\mathrm{C}: \mathrm{N}$ ratio, $\mathrm{pH}$, organic matter, moisture and porosity) and process conditions (time and process) (Khalil et al., 2008). Temperature is another parameter to evaluate evolution of the composting process, since it determines the biological reactions rate, as well as the sanitation capacity of the process. Carbon to $\mathrm{N}$ proportion is a most widely used parameter in composting and cocomposting (Gloueke, 1991). Generally, composting could be carried out under a wide range of initial $\mathrm{C} / \mathrm{N}$ ratios, namely, 11 to 105, depending on the starting materials (Eiland et al., 2001; Ghosh et al, 2007). Tuomela et al. (2000) indicated that initially higher C:N ratio will cause a slower beginning of the process and the required composting time to be longer than usual while Tiquia and Tam (2000) reported that low initial $\mathrm{C}: \mathrm{N}$ ratio results in higher emission of $\mathrm{NH}_{3}$. Huang et al. (2004), by co-composting of pig manure and sawdust at the initial C:N ratios of 30 and 15, reported that the pile with initial C:N ratio of 30 reached maturity within 49 days. Recent studies have shown that composting can be carried out effectively at a lower C:N ratio of 15 (Zhu, 2007). Eiland et al. (2001) composted miscanthus straw with pig slurry at the initial C:N ratio of 11 to 35 with the degradation rate of 40 to $80 \%$. Kumar et al. (2010) found that composting of food waste together with green waste at the initial $\mathrm{C} / \mathrm{N}$ ratio ranging from 14 to 20 was effective with the $\mathrm{C}: \mathrm{N}$ ratio of 19.6. A decrease in the $\mathrm{C}: \mathrm{N}$ ratio implies an increase in the degree of humification of the organic matter.

Composting is a biotechnological process characterized by an initial phase in which different microbial communities degrade organic matter into simpler nutrients and thermophilic temperatures are developed owing to the heat generation. The higher temperatures achieved in this phase appear to be the most important factor in killing heat-sensitive microorganisms. In a second stage, complex organic macromolecules such as humic acids are formed and temperature decreases to ambient levels, leading to a product that may contribute to soil conditioning and fertility (Hsu \& Lo, 1999). Huang et al. (2004) evaluated that composting piles of higher C:N ratio would show a slower rise in temperature, lower maximum temperature and shorter thermophilic phase. Temperature is a simple and excellent indicator of how well the composting process is progressing and how much oxygen is being used (Walker, 2004). Misra et al. (2003) reported that higher temperatures during composting contribute to the killing of weed seeds and pathogens.

The aeration rate (AR) is considered to be the most important factor influencing successful composting (Diaz et al., 2002). Insufficient aeration can lead to anaerobic conditions due to the lack of oxygen, while excessive aeration can increase costs and slow down the composting process via heat, water and ammonia losses. The optimal AR depends on the composition of the raw materials and ventilation methods (Guo et al., 2012). Turning is often cited as the primary mechanism of aeration and temperature control during windrow composting (Michel et al., 1996; Tiquia, 1996), while turning frequency is commonly believed to be a factor which affects the rate of composting as well as compost quality (Tiquia, 1996).

Nitrogen losses can be reduced firstly by adjusting C:N ratio (Lhadi et al., 2004; Meijide et al., 2007); secondly, reducing $\mathrm{N}$ losses by manipulating the temperature changes (Hiraku et al., 2004). Substantial loss of nitrogen results in the reduction of nutrient value of compost products. Among all practicable $\mathrm{N}$ conservation measures, an amendment was thought to be the most efficient method to reduce $\mathrm{N}$ loss during composting. For example, alum, peat, and zeolite lime and coal fly ash amendments have been used to reduce ammonia volatilization and 
heavy metals mobility during composting (Bernal et al., 1993; Kithome et al., 1999; Fang \& Wong, 1999; Qiao $\&$ Ho, 1997). The type of bulking agent had a significant effect. There are a lot of bulking agents that could be used as a carbon source. Farmers make their choice on the basis of the availability of specific bulking agent. To-date, a majority of conducted studies have mainly focused on monitoring the influence of bulking agents on the composting of different types of manure (Petric et al., 2009). Yeoh et al. (2011) reported the selection of an inoculation of bacteria or fungus which may shorten the composting time, improve the compost quality and inhibit the growth of some plant pathogens.

\section{Co-Composting Animal Manure}

Understanding the quantity and quality of waste is an essential step for the productive management of a co-composting process (Yeoh et al., 2011). The factors that affect composting are essential in evaluating the performance of an overall composting process (Yeoh et al., 2011). Karnchanawong and Tadkaew (2013) reported higher nutrient content of the compost and the higher porosity of the soil mixture, as a result of the co-composting of the saw dust, cow dung and egg shells. Dehshan et al. (2013) reported co-compost of cattle manure with rice straw produced an organic matter, total $\mathrm{N}$ and $\mathrm{C}: \mathrm{N}$ ratio contents suitable for soil amendment. Huang et al. (2006) studied the organic matter transformation during co-composting of pig manure with saw dust using chemical and spectroscopic methods and concluded with a stable organic matter in the mature compost. Zhang and He (2005) investigated the physicochemical properties in co-composting of swine manure with pine saw dust and found that $30 \%$ swine manure with initial C:N ratio of about 40 was desirable for composting with organic substrate. The importance of different factors affecting the quality, the stability and the maturation of the co-compost final product by composting pig feces and corn stalks under different aeration rates, $\mathrm{C}: \mathrm{N}$ ratio and moisture content reported that the lowest initial $\mathrm{C}: \mathrm{N}$ ratio had the lowest germination index. Aeration considered to be the main factor affected the stability of the final co-compost product while $\mathrm{C} / \mathrm{N}$ ratio contributed to maturity and moisture content had a significant effect on compost quality (Guo et al., 2012).

Frederick et al. (2003) amended dairy manure of $83 \%$ of moisture with either straw dust or straw and reported that an initial $\mathrm{C} / \mathrm{N}$ ratio more than 40 to minimize $\mathrm{N}$ loss. Li-li et al. (2013) compared the co-composting process of rabbit manure mixed with mushroom residue and rice straw and reported that both compost could help seed growth and a much more efficient way to utilize the material. On comparison, the co-composted manure with rice straw showed significant effects on improving seed growth than with mushroom residue. Dahshan et al. (2013) reported the addition of a bulking agent for composting cattle manure, especially, rice straw which produced compost with an organic matter, total nitrogen, and C:N ratio suitable for soil amendment.

Huang et al. (2006) examined the transformation of organic matter during the co-composting process of pig manure with saw dust. Organic C, C:N ratio and elemental analysis indicated the presences of more stable organic matter in the matured compost. Hao et al. (2004) investigated greenhouse gases emission during composting of straw bedded manure and wood chip bedded manure and concluded that the net contribution of greenhouse gas emission was greater for $\mathrm{CH}_{4}$, since it is 21 times more effective at trapping heat than $\mathrm{CO}_{2}$ and suggested further study to evaluate the impacts of composting on overall greenhouse gases emission and $\mathrm{C}$ sequestration. Wang et al. (2004) investigated the comparison of the co-composting process of dairy manure with wheat straw and sawdust which showed the positive initial plant growth response without fertilization.

The co-composting process of pulp and paper industry sludge with sawdust under aerobic conditions with two different treatments of cow dung only and the one with cow dung with effective microorganisms showed that the pulp and paper industry sludge co-composted with sawdust at the ratio of 3:1 by mixing cow dung and this could have successfully converted into valuable compost (Lakshmi et al., 2010). Eneji et al. (2003) reported that composting farm wastes before soil application could reduce the vulnerable P fraction, while increasing more resistant $\mathrm{P}$ fractions.

Neves et al. (2009) investigated the influence of the lipids content by co-composting cow manure with food waste and concluded with a positive effect due to the oily waste addition. Due to the hydrophobic properties of this specific waste, which may imply reduce need of a bulking agent. Tripetchkul et al. (2012) reported co-composting of coir pith and cow manure to evaluate the influence of $\mathrm{C}: \mathrm{N}$ ratios i.e. 30,25 and 20 on the physicochemical changes and found that simple pile turning yielded effective co-composting of coir pith comparatively with low $\mathrm{C}: \mathrm{N}$ ratio. Considering the composting performance and the amount of coir pith to be utilized, the initial C:N ratio of 30 was considered suitable for coir pith composting. Karnchanawong and Tadkaew (2013) reported higher nutrient contents and vegetable growth using co-compost of saw dust, cow dung and egg-shell and the soil applied with this material was found with higher porosity. Zhang and He et al. (2006) reported total $\mathrm{P}$ loss during mineralization of organic $\mathrm{P}$ and consumption by microbes after co-composting of 
swine manure with pine sawdust. Eneji et al. (2003) reported favorable changes in the organic matter and elemental composition during composting of livestock manure for the use as soil amendment.

\section{Co-Composting of Poultry Manure}

Ogunwande et al. (2008) reported that moisture loss increased as C:N ratio and turning frequency increased when co-composted raw chicken manure with saw-dust. A significant loss of total $\mathrm{N}$ through ammonia volatilization and total $\mathrm{C}$ losses were attributed to the degradation of organic matter. The study indicated that $\mathrm{C}: \mathrm{N}$ ratio significantly affected total $\mathrm{N}$ and $\mathrm{P}$ while $\mathrm{C}: \mathrm{N}$ and turning frequency has a significant effect on total $\mathrm{C}$ and K. Tiquia et al. (2001) reported that co-composting of poultry manure and yard trimmings showed physicochemical and biochemical changes in compost mass, increase in enzymatic activities, decrease in the water soluble components (i.e., water extractable $\mathrm{C}$, inorganic $\mathrm{N}$ and heavy metals) and removal of phytotoxicity. Steiner et al. (2010) focused on reducing $\mathrm{N}$ losses by using poultry litter co composted with biochar which acted as absorber of ammonia and total $\mathrm{N}$ losses were reduced by up to $25 \%$ by lowering ammonia concentration by up to $64 \%$. Salma et al. (2006) co-composted poultry manure, olive mill waste and mineral rich wastewater and reported higher levels of nutrients, low $\mathrm{C}: \mathrm{N}$ ratio of $15-17$, free of phytotoxicity in co-compost and no negative impacts on soils. Tiquia and Tam (2000) examined the changes of $\mathrm{N}$ during co-composting of chicken litter i.e. the mixture of chicken manure, wood shaving, waste feed and feathers, reduced the value of chicken litter as $\mathrm{N}$ fertilizer and contained more stable organic matter in composted chicken litter. Huck et al. (2013) co-composted pine apple leaves and chicken slurry and reported no foul odor, low heavy metals content and considerable amount of nutrients with phytotoxic free seed germination.

\section{Co-Composting of Municipal Solid Waste}

Marco et al. (2013) used disposed white rot fungus Trametesversicolor after its application in the biotechnological process and co-composted with organic fraction of municipal solid waste and suggested that the final compost obtained through co-composting process ensured the higher stable final product than that obtained through organic fraction of municipal solid waste composting. Municipal solid waste with cow manure, poultry manure and yard trimmings etc helped to maintain soil fertility and improved moisture holding capacity of soils and found an acceptable release of plant nutrients (Gautam et al., 2010). Fourti et al. (2008) assessed co-composting of municipal solid waste and sewage sludge in semi-arid pedo-climatic conditions and finally confirmed amongst others that temperature is the main parameter to consider in composting since it acclimatizes the functioning of all the others parameters, specifically the microbial activity and diversity.

\section{Co-Composting of Sludge}

The effects of bamboo charcoal on $\mathrm{N}$ conservation and $\mathrm{Cu}, \mathrm{Zn}$ mobility during sludge composting concluded that $\mathrm{N}$ loss and $\mathrm{Cu}$ and $\mathrm{Zn}$ mobility could significantly lessened through bamboo charcoal capability of ammonia adsorption (Hua et al., 2009). Wu et al. (2010) carried out $\mathrm{N}$ transformation during co-composting of herbal residue, spent mushrooms and sewage sludge at different ratios of 3:1:1 (sewage sludge:sawdust:spent mushrooms or herbal residue) and 3:1:2 (sewage sludge:sawdust:spent mushrooms or herbal residue) and concluded that the germination index values for all samples at maturity were above $80 \%$, demonstrating optimal maturity. The addition of spent mushrooms or herbal residues augmented sewage composting.

The microbial and enzymatic activities during co-composting process of empty fruit bunches and partially treated with palm oil mill effluent showed that different species of uncultured bacteria dominated the process from the phylum proteobacteria in the thermophilic stage to the phylum chloroflexi in the maturing stage (Baharuddin et al., 2009). Hock et al. (2009) investigated the characteristics and physicochemical changes in the windrow in co-composting process of oil palm mesocarp fiber and palm oil mill effluent with anaerobic sludge. The final co composted product was achieved within 50 days with C:N ratio of 12.6 with considerable amount of nutrients and low levels of heavy metals.

\section{Use of Co-Composted Waste Material}

\subsection{Nitrogen/Carbon Losses during Co-Composting}

Composting is a bio-oxidative process in which organic matter is transformed by $\mathrm{N}$ mineralization, ammonia volatilization, nitrification, denitrification and partial humification into compost which is free of phyto-toxicity, pathogens and with certain humic properties by aerobic microorganisms. It comprises three major phases: mesophilic, thermophilic and cooling phase (the compost stabilization phase) (Tiquia \& Tam, 2000; Singh \& Kalamdhad, 2012; Neves et al., 2009). Nitrogen mineralization is of extreme importance because it converts organic $\mathrm{N}$ into ammonium $\left(\mathrm{NH}_{4}\right)$. Ammonia $\left(\mathrm{NH}_{3}\right)$ volatilization and de-nitrification may lead to significant losses of N (Martins \& Dewes, 1992; Bernal et al., 1996). One of the most negative effects of composting animal 
manures is the loss of $\mathrm{N}$ through $\mathrm{NH}_{3}$ volatilization which reduces the fertilizer value of the manure and constitutes an important economic loss (Tiquia \& Tam, 2000). Ammonia emissions result from aerobic or anaerobic bacteria in manure (Zhang et al., 1991). Several studies have shown that $\mathrm{NH}_{3}$ volatilization increased with an increase in $\mathrm{pH}$, moisture content, aeration, $\mathrm{NH}_{3}$ concentration or temperature (Bishop \& Godfrey, 1983). These losses during composting of animal manure range from 21\% upward to $77 \%$ (Martins \& Dewes, 1992; Rao Bhamidimarri \& Pandey, 1996). Nitrogen losses varied depending on several environmental factors such as aeration, moisture content, and temperature (Bishop \& Godfrey, 1983). Ogunwande et al. (2008) reported that $\mathrm{C}: \mathrm{N}$ ratio had significant $(P \leq 0.05)$ effect on pile temperature, total $\mathrm{N}$, total $\mathrm{C}, \mathrm{C}: \mathrm{N}$ ratio, dry matter, $\mathrm{P}$ and $\mathrm{K}$ while turning frequency had significant $(P \leq 0.05)$ effect on pile temperature, $\mathrm{pH}, \mathrm{TC}, \mathrm{C}: \mathrm{N}$ ratio and $\mathrm{K}$. The decreasing level of $\mathrm{C}: \mathrm{N}$ ratio is correlated by the loss of TOC to produce carbon dioxide and smaller increase of nitrogen as the decomposition progressed. The decreasing pattern of the C:N ratio and TOC, and the increasing pattern of nitrogen content were reported by Abdullah et al. (2013) and Goyal et al. (2005) on sugarcane trash, cattle dung, pressmud, poultry waste and water hyacinth composting. The key to the development of compost technology is to control the changes and $\mathrm{N}$ losses, and this has attracted the attention of many compost researchers (Cordovil et al., 2007; Meijide et al., 2007; Wu et al., 2010; Huang et al., 2005; Hua et al., 2009).

Apart from N, C is another element that is most likely to be lost during the composting process. Zhang and He (2006) reported that $\mathrm{N}$ and $\mathrm{P}$ decomposition primarily occurred in the mesophilic phase, while organic carbon decomposed in the thermophilic phase during co-composting of solid swine manure with pine sawdust and 30\% swine manure with initial $\mathrm{C}: \mathrm{N}$ ratio of about 40 was more desirable for composting organic substrates. The nutrient loss especially nitrogen is an unavoidable problem during the composting of organic waste (Cooperband \& Middleton, 1996; Rao \& Pandey, 1996). Carbon may be lost due to either bio-oxidation, in which carbonaceous materials are lost as $\mathrm{CO}_{2}$ (Bishop \& Godfrey, 1983; Eghball et al., 1997) or mineralization of C, in which inorganic $\mathrm{C}$ is converted to organic $\mathrm{C}$ (Bernal et al., 1998). The compost quality could further be improved by adding cow manure, poultry manure or yard waste etc (Gautam et al., 2010). The adjustment of the C:N ratio of lingo-cellulosic composts by the addition of $\mathrm{N}$ source from animal residues proved to a reliable composting process and the end products characterized by a good degree of stability, and compatible with safe and effective soil utilization (Cayuela et al., 2009).

\subsection{Effects of Co-Composting on Soil Quality}

The application of stabilized co-composted manure to soil can affect soil fertility by improving physical, chemical and biological properties of the soil (Dick et al., 1993). The physical changes involve modifications of soil bulk density, structure, strength and water relations. The chemical changes include the accumulation of organic plant nutrients, the soil's ion exchange capacity, chelating activity and buffering ability. Composted animal manure can enlarge the nutritional base for soil microorganisms. Incorporated manure composts also become part of the soil humus and employ their influence on long-term basis. Such inclusions of soil amendments are particularly important where the soils are poor enough in terms of OM content (Tiquia \& Tam, 2002).

The effect of compost on soil $\mathrm{pH}$ depends both on the initial $\mathrm{pH}$ of the compost and the soil $\mathrm{pH}$ (Tiquia \& Tam, 2002). Organic amendments significantly increase the soil reducing exchangeable acidity, exchangeable $\mathrm{Al}$, and exchangeable $\mathrm{Fe}$ that altered soil chemical properties in a way that enhanced the availability of phosphorus $\mathrm{pH}$ (Schulz et al., 2014; Chng et al., 2014). Manures have been proven to lower the pH of alkaline soils (Chang et al., 1991). Increasing the $\mathrm{pH}$ of acidic soils has also been demonstrated frequently by the use of livestock manure (Hue, 1992; Whalen et al., 2000; Baziramakenga et al., 2001). Elamin (1991) demonstrated that the decomposition of organic matter tended to improve the soil physical and chemical proprieties.

End product of co-composted plant residues and animal manure greatly influence the biochemical and structural properties of the soil. Mineralization of plant residue has been demonstrated to be the best soil amendment and animal manures as organic fertilizer (Mondini et al., 2010). The addition of plant residues tended to increase the microbial pool due to lack of $\mathrm{N}$ availability, the addition of animal by-products led to the rapid increase of the microbial biomass (Cayuela et al., 2008). Co-composted biochar incorporation induced soil alkalization which increasd soil nitrification (Lehmann et al., 2003; Yamato et al., 2006; Amlinger et al., 2007).

\subsection{Heavy Metals during Co-Composting}

Compost usually contains heavy metals based on initial raw material. Generally, these heavy metals (micronutrients) are essential for plant growth. The micronutrients present in the compost, such as $\mathrm{Zn}, \mathrm{Cu}$ and Fe, are utilized by the plants during the fertilizing process. These trace elements are required for a better plant growth in trace quantities but in large quantities can cause phytotoxicity, consequently can impose hazardous 
risks to human and fauna (Eneji et al., 2003; Simth, 2009; Van Herwijnen et al., 2007). However, constant and extensive application of organic compost will lead to the accumulation of heavy metals in the soil and an increase in toxic levels. Heavy metals can render the growth, morphology and metabolism of soil microorganisms, consequently affect the fertility of soil reduced (Bragato et al., 1998). Uptake of heavy metals by plants and successive accumulation in human tissues and bio magnifications by the food chain can adversely affect human health and environment concerns (Wong et al., 2006; Chiroma et al., 2013). Addition of lime during composting process, natural zeolite and bamboo charcoal amendments tend to immobilize metals and reduced heavy metals availability and leachibility. (Singh \& Kalamdhad, 2013) suggested that bioavailability and leachability of metals should be assessed before adding composted manure to the agricultural fields. Composting process tended to increase total $\mathrm{P}, \mathrm{K}, \mathrm{Cu}$, and $\mathrm{Zn}$ (Jusoh et al., 2013) due to the losses of organic $\mathrm{C}, \mathrm{H}, \mathrm{N}$, and $\mathrm{O}$ in the forced-aeration piles as demonstrated by (Tiquia \& Tam, 2002) where $\mathrm{CO}_{2}$ and $\mathrm{H}_{2} \mathrm{O}$ during composting process, leaving $\mathrm{Cu}$ and $\mathrm{Zn}$ behind and giving a relative increase in the concentrations of these elements. The organic amendments tend to increase organic P compared with soil alone as showed by Chang et al. (2014). Moreover the high sorption capacity caused by aromaticity of the bio char (co-composted) influenced nutrient cycling (Glaser et al., 2002). Biochar applied in higher amounts, soil nutrient availability increased in highly weathered tropical soils comparable (Lehmann et al, 2002, with $560 \mathrm{Mg} \mathrm{ha}^{-1}$; Lehmann et al., 2003, with 67.6-135.2 $\mathrm{Mg} \mathrm{ha}^{-1}$; Steiner et al., 2007, with $11 \mathrm{Mg} \mathrm{ha}^{-1}$ ). According to Kostov et al. (1995), compost had a significant impact over manure in respect of nutrient release.

\subsection{Bulk Density during Co-Composting}

Reduction in soil bulk density may be expected when soil is mixed with less dense organic material, but there may also be associated with alteration of soil structure. The magnitude of change for bulk density and other soil properties likely to vary with soil texture as demonstrated by Aggelides and Londra (2000). Decreased bulk density and increased water holding capacity of soil have been characterized by the addition of the organic amendments. Bulking agents acted as moisture adjuster due to their low moisture level and higher cellulose content, which can be a source of carbon (Abdullah et al., 2013). The addition of bulking agent (yard trimmings, woodchips, rice husks) to the chicken litter help to reduce the loss of $\mathrm{N}$ by reducing ammonia loss (Wan et al., 1999, Tiquia \& Tam, 2000). The decrease bulk densities and increase soil water holding capacities of the organically amended treatments in comparison to the control is due to enhanced aggregation of soil particles by the addition of organic matter (Khaleel et al., 1981; Grandy et al., 2002; Elsharawy et al., 2003).

\subsection{Agronomic Benefits of Co-Composting}

Plant growth significantly increased with compost amendment (Schulz et al., 2014). Co-composting rabbit manure with rice straw and mushroom residues was found efficient to utilize the material to enhance seed production (Li-li et al., 2013). Chicken manure resulted in an increase growth attributes as well as forage yield as indicated by Ismaeil et al. (2012). Several researchers reported that nitrogen and phosphorus uptake, as a function of chicken manure application, progressively exceeded with composted manure (Magid et al., 1998; Postma et al., 1998; Hue \& Sobieszczyk, 1999; Abusuwar \& El Zalal, 2010). The increase in organic P with the increasing of time is essential to mineralize $\mathrm{P}$ in soil for crop use and influenced the crop yield and growth (Chang et al., 2014). Agronomic considerations including increase crop productivity, reduced fertilizer and pesticide use have been reported with the application of composted manure (Schulz \& Glaser, 2013; Jaffery et al., 2011; Blackwell et al., 2013).

\section{Conclusions}

Co-composting is an effective solid waste management that helps to manage a variety of solid waste (poultry waste, animal waste, food waste agro-waste, municipal solid waste, industrial sludges and effluents etc.) and converts them into a valuable product that may enhance the fertility of the soil by acting as soil conditioner. This process is simple having lowest operational cost and an alternative of costly fertilizer used for enhancing the soil nutrients. The process of co-composting can help to promote the complexation of heavy metals whose mobility and availability tend to decrease with decreasing toxicity. Bio-degradable waste can successfully be co-composted with different types of organic wastes to get higher quality cocomposted product. There is a need to study quality characteristics and possible benefits of compost.

\section{References}

Abdullah, N., Chin, N. L., Mokhtar, M. N., \& Saleena, F. T. (2013). Effects of bulking agents, load size or starter cultures in kitchen waste composting. International Journal of Recycling of Organic Waste in Agriculture, 3, $1-10$. 
Aggelides, S. M., \& Londra, P. A. (2000). Effects of compost produced from town wastes and sewage sludge on the physical properties of a loamy and a clay soil. Bioresource Technology, 71, 253-259. http://dx.doi.org/10.1016/S0960-8524(99)00074-7

Abusuwar, A. O., \& El Zalal, H. A. (2010). Effect of chicken manure on yield, quality and HCN concentration of two forage Sorghum (Sorghum bicolor L. (Moench) cultivars. Agriculture and Biology Journal of North America, 1(1), 27-31.

Amlinger, F., Peyr, S., Geszti, J., Dreher, P., Karlheinz, W., \& Nortcliff, S. (2007). Beneficial Effects of Compost Application on Fertility and Productivity of Soils. Federal Ministry for Agricultural and Forestry, Environment and Water Management. Lebensministerium: Vienna, Austria.

Bishop, P. L., \& Godfrey, C. (1983). Nitrogen variations during sludge composting. BioCycle, 24, 34-40.

Baharuddin, A. S., Wakisaka, M., Shirai, Y., Abd-Aziz, S., Abdul Rahman, N. A., \& Hassan, M. A. (2009). Co-composting of empty fruit bunches and partially treated palm oil mill effluents in pilot scale. International Journal of Agricultural Research, 4, 69-78. http://dx.doi.org/10.3923/ijar.2009.69.78

Barrington, S., Choiniere, D., Trigui, M., \& Knight, W. (2002). Effect of carbon source on compost nitrogen and carbon losses. Bioresource Technology, 83, 189-194. http://dx.doi.org/10.1016/S0960-8524(01)00229-2

Baziramakenga, R., Simard, R. R., \& Lalande, R. (2001). Effect of de-inking paper sludge compost application on soil chemical and biological properties. Canadian Journal of Soil Science, 81, 561-575. http://dx.doi.org/10.4141/S00-063

Bernal, M. P., Lopez-Real, J. M., \& Scott, K. M. (1993). Application of natural zeolites for the reduction of ammonia emission during the composting of organic waste in a laboratory composting simulators. Bioresource Technology, 43, 35-39. http://dx.doi.org/10.1016/0960-8524(93)90079-Q

Bernal, M. P., Paredes, C., Sánchez-Monedero, M. A., \& Cegarra, J. (1998). Maturity and stability parameters of composts prepared with a wide range of organic wastes. Bioresource Technology, 63, 91-99. http://dx.doi.org/10.1016/S0960-8524(97)00084-9

Bernal, M., Navarro, A. F., Roig, A., Cegarra, J., \& Garcia, D. (1996). Carbon and nitrogen transformation during composting of sweet sorghum bagasse. Biology and Fertility of Soils, 22, 141-148. http://dx.doi.org/10.1007/BF00384446

Barrington, S., Choiniere, D., Trigui, M., \& Knight, W. (2002). Effect of carbon source on compost nitrogen and carbon losses. Bioresource Technology, 83, 189-194. http://dx.doi.org/10.1016/S0960-8524(01)00229-2

Blackwell, P., Krull, E., Butler, G., Herbert, A., \& Solaiman, Z. (2013). Effect of banded biochar on dryland wheat production and fertiliser use in south-western Australia: An agronomic and economic perspective. Soil Research, 48, 531-545. http://dx.doi.org/10.1071/SR10014

Bragato, G., Leita, L., Figliolia, A., \& Nobili, M. (1998). Effects of sewage sludge pre-treatment on microbial biomass and bioavailability of heavy metals. Soil Tillage Research, 46, 129-134. http://dx.doi.org/10.1016/S0167-1987(97)00084-6

Burton, H., \& Turner, C. (2003). Treatment Strategies for sustainable Agriculture. Manure management (2nd ed.). Silsoe Institute, Lister and Durling printers. Flitwick Bedford, UK.

Cayuela, M. L., Sinnico, T., \& Mondini, C. (2009). Mineralization dynamics and biochemical properties during initial decomposition of plant and animal residues in soil. Applied Soil Ecology, 4, 118-127. http://dx.doi.org/10.1016/j.apsoil.2008.10.001

Chang, H. Y., Ahmad, O. H., Kassim, S., \& Majid, N. M. A. (2013). Co-composting of pineapple leaves and chicken slurry. International Journal of Recycling of Organic Waste in Agriculture, 2(23), 1-8.

Chang, H. Y., Ahmed, O. H., \& Majid, N. M. A. (2014). Improving phosphorous availability in an acid soil using organic amendments produced from agro industrial wastes. The Scientific World Journal, 10, 1-6. http://dx.doi.org/10.1155/2014/794756

Chiroma, T. M., Ebewele, R. O., \& Hymore, F. K. (2012). Levels of heavy metals ( $\mathrm{Cu}, \mathrm{Zn}, \mathrm{Pb}, \mathrm{Fe}$ and $\mathrm{Cr}$ ) in bush green and roselle irrigated with treated and untreated urban sewage water. International Research Journal of Environmental Sciences, 1, 50-55.

Cordovil, C. M. D. S., Cabral, F., \& Coutinho, J. (2007). Potential mineralization of nitrogen from organic wastes to ryegrass and wheat crops. Bioresource Technology, 98, 3265-3268. 
http://dx.doi.org/10.1016/j.biortech.2006.07.014

Dahshan, H., Abd- Elall, A. M. M., Abd-El-Kader, M. A., \& Megahed, A. M. (2013). Field-scale management and evaluation of recycled cattle manure solids from livestock in Nile Delta ecosystem. African Journal of Agricultural Research, 8, 2829-2836.

Diaz, M. J., Madejon, E., Lopez, F., Lopez, R., \& Cabrera, F. (2002). Optimization of the rate vinasse/grape marc for co-composting process. Process Biochemistry, $37, \quad$ 1143-1150. http://dx.doi.org/10.1016/S0032-9592(01)00327-2

Dick, W. A., \& McCoy, E. I. (1993). Enhancing soil fertility by addition of compost. In H. A. J. Hoitink, \& H. M. Keener (Eds.), Science and engineering of composting: Design, environmental, microbiological and utilization aspects (pp. 623-644). Worthington, Ohio: The Renaissance Publications.

Eghball, B., Power, J. F., Gilley, J. E., \& Doran, J. W. (1997). Nutrient, carbon and mass loss during composting of beef cattle feedlot manure. Journal of Environmental Quality, 26, 189-193. http://dx.doi.org/10.2134/jeq1997.261189x

Eneji, A. E., Yamamoto, S., Honna, T., \& Ishiguro, A. (2001). Physico-chemical changes in livestock feces during composting. Communications in Soil Science and Plant Analysis, 32, 477-489. http://dx.doi.org/10.1081/CSS-100103023

Eneji, A. E., Honna, T., Yamamoto, S., Masuda, T., \& Irshad, M. (2003). Changes in humic substances and phosphorus fractions during composting. Communications in Soil Science and Plant Analysis, 34, 2303-2314. http://dx.doi.org/10.1081/CSS-120024065

Eneji, E., Honna, T., Yamamoto, S., Masuda, T., Endo, T., \& Irshad, M. (2003). The relationship between total and available heavy metals $\mathrm{n}$ composted manure. Journal of Sustainable Agriculture, 23, $125-134$. http://dx.doi.org/10.1300/J064v23n01_09

Eiland, F., Klamer, M., Lind, M. A., Leth, M., \& Bååth, E. (2001). Influence of initial C/N ratio on chemical and microbial composition during long term composting of straw. Microbiology and Ecology, 41, 272-280.

Elamin, E. E. (1991). Effect of organic manure decomposition on some soil properties (M. Sc (Agric). Thesis). Faculty of Agriculture, University of Khartoum, Sudan.

Fang, M., Wong, J. W. C., Ma, K. K., \& Wong, M. H. (1999). Co-composting of sewage sludge and coal ash: $\begin{array}{lllll}\text { nutrient } & \text { transformation. } & \text { Bioresource } & \text { Technology, } & \text { 67, }\end{array}$ http://dx.doi.org/10.1016/S0960-8524(99)00095-4

Fourti, O., Haydri, Y., Murano, F., Jedidi, N., \& Hassen, A. (2008). A new process assessment of co composting of municipal solid waste and sewage sludge in semi arid pedo climate condition. Annals of Microbiology, 58, 403-409. http://dx.doi.org/10.1007/BF03175535

Gajdos, R. (1992). The use of organic waste materials as organic fertilizer - Recycling of plant nutrients. Acta Horticulturae, 302, 325-331.

Gautam, S. P., Bundela, P. S., Pandey, A. K., Awasthi, M. K., \& Sarsaiya, S. (2010). Composting of municipal solid waste of Jabalpur city. Global Journal of Environmental Research, 4, 43-46.

Glaser, B., Lehmann, J., \& Zech, W. (2002). Ameliorating physical and chemical properties of highly weathered soils in the tropics with charcoal- A review. Biology and Fertility of Soils, 35, 219-230. http://dx.doi.org/10.1007/s00374-002-0466-4

Ghosh, P. K., Sarma, U. S., Ravindranath, A. D., Radhakrishman, S., \& Ghosh, P. (2007). A novel method for accelerated composting of coir pith. Energy Fuel, 21, 822-827. http://dx.doi.org/10.1021/ef060513c

Golueke, C. G. (1991). Principle of Composting. The staff of Biocycle Journal of Waste Recycling. The art and science of composting (pp. 32-55). JG Press, Pennsylvania.

Guo, R., Li, G., Jiang, T., Schuchardt, F., Chen, T., Zhao, Y., \& Shen, Y. (2012). Effect of aeration rate, C/N ratio and moisture content on the stability and maturity of compost. Bioresource Technology, 112, 171-178. http://dx.doi.org/10.1016/j.biortech.2012.02.099

Hachicha, S., Chtourou, M., Medhioub, K., \& Ammar, E. (2006). Compost of poultry manure and olive mill waste as an alternative fertilizer. Agronomy for Sustainable Development, 26, $135-142$. http://dx.doi.org/10.1051/agro:2006005

Herwijnen, V. R. (2007). Remediation of metal contaminated soil with mineral amended compost. 
Environmental Pollution, 150, 357-54.

Herwijnen, R. V., Hutchings, T. R., Tabbaa, A. A., Moffat, A. J., Johns, M. L., \& Ouki, S. K. (2007). Remediation of metal contaminated soil with mineral amended composts. Environmental Pollution, 150, 347-354. http://dx.doi.org/10.1016/j.envpol.2007.01.023

Hiraku, S., Gen, M., Hanatsu, S., Jun, N., Msaaki, S., Takako, S., .. Yutaka, N. (2004). Distribution of ammonia assimilating bacteria in the composting process. Compost Science and Utilization, 12, 108-113. http://dx.doi.org/10.1080/1065657X.2004.10702168

Hock, L. S., Baharuddin, A. S., Ahmad, M. N., \& Shah, U. K. (2009). Physicochemical changes in windrow co-composting process of oil palm mesocrap fiber and palm oil mill effluent anaerobic sludge. Australian Journal of Basic and Applied Sciences, 3(3), 2809-2816.

Hua, L., Wu, W., \& Liu, Y. (2009). Reduction of nitrogen loss and $\mathrm{Cu}$ and $\mathrm{Zn}$ mobility during sludge composting with bamboo charcoal amendment. Environmental Science and Pollution Research, 16, 1-9. http://dx.doi.org/10.1007/s11356-008-0041-0

Huang, G. F., Wu, Q. T., Wong, J. W. C., \& Nagar, B. B. (2006). Transformation of organic matter during co-composting of pig manure with saw dust. Bioresource Technology, 97, 1834-1842. http://dx.doi.org/10.1016/j.biortech.2005.08.024

Huang, G. F., Wong, J. W. C., Wu, Q. T., \& Nagar, B. B. (2004). Effect of C/N on composting of pig manure with sawdust. Waste Management, 24(8), 805-813. http://dx.doi.org/10.1016/j.wasman.2004.03.011

Hue, N. V., \& Sobieszczyk, B. A. (1999). Nutritional values of some bio-wastes as soil amendments. Compost Science and Utilization, 7, 34-41. CAB Abstracts, 98/2000. http://dx.doi.org/10.1080/1065657X.1999.10701950

Hue, N. V. (1992). Correcting soil acidity of a highly weathered Ultisol with chicken manure and sewage sludge. Communications in Soil Science and Plant Analysis, 23, 241-264. http://dx.doi.org/10.1080/00103629209368586

Hsu, J. H., \& Lo, S. L. (1999). Chemical and spectroscopic analysis of organic matter transformations during composting of pig manure. Environmental Pollution, 104, 189-196. http://dx.doi.org/10.1016/S0269-7491(98)00193-6

Ismaeil, F. M., Abusuwar, A. O., \& Naim, A. M. E. (2012). Influence of chicken manure on growth anf yield of Sorghum (Sorghum biocolor L. Moench). International Journal of Agriculture and Forestry, 2(2), 56-60. http://dx.doi.org/10.5923/j.ijaf.20120202.09

Jeffery, S., Verheijen, F. G. A., Van der Velde, M., \& Bastos, A. C. (2011). A quantitative review of the effects of biochar application to soils on crop productivity using meta-analysis. Agriculture, Ecosystems and Environment, 144, 175-187. http://dx.doi.org/10.1016/j.agee.2011.08.015

Jusoh, M. L. C., Manaf, L. A., \& Latiff, P. A. (2013). Composting of rice straw with effective microorganisms (EM) and its influence on compost quality. Journal of Environmental Health Science and Engineering, 10, 17-26. http://dx.doi.org/10.1186/1735-2746-10-17

Kashmanian, R. M. (2000). Quantities, Characteristics, Barriers and Incentives for use of Organic Municipal By products, Land Application of Agricultural, Industrial and Municipal By-products. Science Society of America Books Series, 6, 128-167.

Karnchanawong, S., \& Tadkaew, N. (2013). Effects of compost from co composting of sawdust, cow dung and eggshell on soil acidity neutralization and growth of vegetable. Digital proceeding of the ICOEST'2013. Nevsehir, Turkey. June 18-21, 2013.

Kithome, M., Paul, J. W., \& Bomk, A. A. (1999). Reducing nitrogen losses during simulated composting of poultry manure using absorbents or chemical amendments. Journal of Environmental Quality, 28, $194-201$. http://dx.doi.org/10.2134/jeq1999.00472425002800010023x

Kostov, O., Tzvetkov, Y., Kaloianova, N., \& Cleemput, O. (1995). Cucumber cultivation on some waste during their aerobic composting. Bioresource Technology, 53, 237-242. http://dx.doi.org/10.1016/0960-8524(95)00076-Q

Kumar, M., Ou, Y. L., \& Lin, J. G. (2010). Co-composting of green waste and food waste at low C/N ratio. Waste Management, 30, 602-609. http://dx.doi.org/10.1016/j.wasman.2009.11.023 
Lehmann, J., Pereira da Silva, J., Steiner, C., Nehls, T., Zech, W., \& Glaser, B. (2003). Nutrient availability and leaching in an archaeological Anthrosol and a Ferralsol of the Central Amazon basin: Fertilizer, manure and charcoal amendments. Plant and Soil, 249, 343-357. http://dx.doi.org/10.1023/A:1022833116184

Lehmann, J., Da Silva, J. P. Jr., Rondon, M., Cravo, M. S., Greenwood, J., Nehls, T., \& Steiner, C. (2002). Slash-and-char- A feasible alternative for soil fertility management in the Central Amazon. Proceedings of the $17^{\text {th }}$ World Congress of Soil Science. Bangkok, Thailand, August 14-21, 2002.

Lhadi, E. K., Tazi, H., Aylaj, M., Tambone, F., \& Adani, F. (2004). Co-composting separated MSW and poultry manure in Morocco. Compost Science and Utilization, 121, 37-144.

Li-Li, B., Tie-Jun, Y., Bin, W., Lin, B., De-gui, T., \& Xiang-Chao, F. (2013). Evaluation and comparison of composting rabbit manure mixed with mushroom residue and rice straw. Journal of Agricultural Science and Technology, 15, 1069-1081.

Lokman, M., Jusoh, C., Manaf, L. A., \& Latiff, A. (2013). Composting of rice straw with effective microorganisms (EM) and its influence on compost quality. Journal of Environmental Health Science and Engineering, 10, 1-9.

Meijide, A., Diez, J. A., Sanchez-Martin, L., Lopez-Femandez, S., \& Vakkejo, A. (2007). Nitrogen oxide emissions from an irrigated maize crop amended with treated pig slurries and composts in a Mediterranean

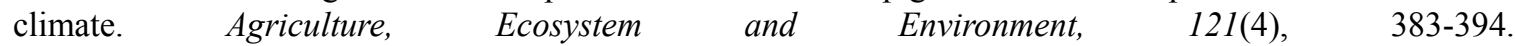
http://dx.doi.org/10.1016/j.agee.2006.11.020

Magid, H. M., Abdel Al, S. I., Rabie, R. K., \& Sabra R. E. (1998). Chicken manure as a bio-fertilizer for wheat gown in sandy soils of Saudi Arabia. Egyptian Journal of Soil Science, 38, 329-338.

Martins, O., \& Dewes, T. (1992). Loss of nitrogenous compounds during composting of animal wastes. Bioresource Technology, 42, 103-111. http://dx.doi.org/10.1016/0960-8524(92)90068-9

Michel, F. C., Forney, L. J., Huang, A. J. F., Drew, S., Czuprendski, M., Lindeberg, J. D., \& Reddy, C. A. (1996). Effects of turning frequency, leaves to grass mix ratio and windrow vs. pile configuration on the composting of yard trimmings. Compost Science and Utilization, 4, 126-143. http://dx.doi.org/10.1080/1065657X.1996.10701816

Michel, F. C. J., Pecchia, J. A., Rigot, J., \& Keener, H. M. (2003). Mass and nutrient losses during composting of dairy manure with sawdust versus straw amendment. Compost Science and Utilization, 23, 1-33.

Misra, R. V., Roy, R. N., \& Hiraoka, H. (2003). On-farm composting methods. FAO Corporate Document Repository. Retrieved from http://www.fao.org/docrep/007/y5104e/y5104e05.htm

Mondini, C., Sinicco, T., \& Cayuela, M. L. (2010). Mineralization dynamics and biochemical properties following application of organic residue to soil. $19^{\text {th }}$ World Congress of Soil Sc, soil solutions for a changing World. August 1-6, 2010, Brisbane, Australia.

Neves, L., Ferreira, V., \& Oliveira, R. (2009). Co-composting cow manure with food waste: The influence of lipid content. World Academy of Science, Engineering and Technology, 58, 986-991.

Ogunwande, G. A., Osunade, J. A., \& Ogunjimi, L. A. O. (2008). Effects of carbon to nitrogen ratio and turning frequency on composting chicken litter in turned windrow piles. CIGR E-journal, X, 1-16.

Postma, R., Erp, P. V., \& Van, E. P. (1998). Nutrient management in arable farming and outdoor vegetable growing. Mestoto Hen, 13-19. CAB Abstract 1998/99.

Petric, I., Sestan, A., \& Sestan, I. (2009). Influence of wheat straw addition on composting of poultry manure. Process Safety and Environmental Protection, 78, 206-212. http://dx.doi.org/10.1016/j.psep.2009.02.002

Petrica, I., Šestan, A., \& Šestan, I. (2009). Influence of initial moisture content on the composting of poultry manure with wheat straw. Biosystems Engineering, 10, 125-134. http://dx.doi.org/10.1016/j.biosystemseng.2009.06.007

Qiao, L., \& Ho, G. (1997). The effects of clay amendment and composting on metal speciation in digested sludge. Water Research, 31, 951-964. http://dx.doi.org/10.1016/S0043-1354(96)00289-8

Rao Bhamidimarri, S. M., \& Pandey, S. P. (1996) Aerobic thermophilic composting of piggery solid wastes. Water Science and Technology, 33(8), 89-94. http://dx.doi.org/10.1016/0273-1223(96)00265-X

Schulz, H., Dunst, G., \& Glaser, B. (2013). Positive effects of composted biochar on plant growth and soil $\begin{array}{llll}\text { fertility. Agronomy for Sustainable Development, } & 33, \text { 817-827. }\end{array}$ 
http://dx.doi.org/10.1007/s13593-013-0150-0

Schulz, H., Dunst, G., \& Glasser, B. (2014). No effect of co-composted biochar on plant growth and soil properties in a greenhouse experiment. Agronomy, 4, 34-51. http://dx.doi.org/10.3390/agronomy4010034

Smith, S. R. (2009). A critical review of the bioavailability and impacts of heavy metals in municipal solid waste composts compared to sewage sludge. Environment International, 35, 142-156. http://dx.doi.org/10.1016/j.envint.2008.06.009

Steiner, C., Das, K. C., Melear, N., \& Lakly, D. (2010). Reducing nitrogen loss during poultry litter composting using biochar. Journal of Environmental Quality, 39. http://dx.doi.org/10.2134/jeq2009.0337

Steiner, C., Teixeira, W., Lehmann, J., Nehls, T., de Macêdo, J., Blum, W., \& Zech, W. (2007). Long term effects of manure, charcoal and mineral fertilization on crop production and fertility on a highly weathered Central Amazonian upland soil. Plant and Soil, 291, 275-290. http://dx.doi.org/10.1007/s11104-007-9193-9

Singh, J., \& Kalamdhad, A .S. (2013). Bioavailability and leachability of heavy metals during composting. A review. International Research Journal of Environmental Science, 2(4), 59-64.

Thyagarajan, L. P., Meenambal, T., Mangaleshwaran, L., \& Lashminarasimaiah, N. (2010). Recycling of pulp and paper industry sludge with sawdust by aerobic composting method. Nature Environment and Pollution Technology, 1, 149-154.

Tiquia, S. M., Richard, T. L., \& Honeyman, M. S. (2000). Effects of windrow turning and seasonal temperatures on composting of hog manure from hoop structures. Environmental Technology, 21, 1037-1046. http://dx.doi.org/10.1080/09593332108618048

Tiquia, S. M., Tam, N. F. Y., \& Hodgkiss, I. J. (1996). Microbial activities during composting of spent pig-manure sawdust litter at different moisture contents. Bioresource Technology, 55, 201-206. http://dx.doi.org/10.1016/0960-8524(95)00195-6

Tiquia, S. M., \& Tam, N. F. Y. (2000). Fate of nitrogen during composting of chicken litter. Environmental Pollution, 110, 535-541. http://dx.doi.org/10.1016/S0269-7491(99)00319-X

Tiquia, S. M., \& Tam, N. F. Y. (2002). Characterization and composting of poultry litter in forced aeration piles. Process Biochemistry, 37, 869-880. http://dx.doi.org/10.1016/S0032-9592(01)00274-6

Tripetchkul, S., Pundee, K., Koonsrisuk, S., \& Akeprathumchai, S. (2012). Co-composting of coir pith and cow manure, initial $\mathrm{C} / \mathrm{N}$ ratio $\mathrm{Vs}$ physicochemical changes. International Journal of Recycling of Organic Waste in Agriculture, 1(15). http://dx.doi.org/10.1186/2251-7715-1-15

Tuomela, M., Vikman, M., Hatakka, A., \& Itavaara, M. (2000). Biodegradation of lignin in a compost environment: A $\quad$ Bioresource Technology, $169-183$. http://dx.doi.org/10.1016/S0960-8524(99)00104-2

Vallini, M. G., \& Pera, A. (1983). The biology of cornposting: A review. Waste Management Research, 1, 157-176. http://dx.doi.org/10.1177/0734242X8300100118

Whalen, J. K., Chang, C., Clayton, G. W., \& Carefoot, J. P. (2000). Cattle manure amendments can increase the $\mathrm{pH}$ of acid soils. Soil Science Society of America Journal, 64, 962-966. http://dx.doi.org/10.2136/sssaj2000.643962x

Walker, F. (2004). On-farm composting of poultry litter. The Agricultural Extension Service, The University of Tennessee Institute of Agriculture.

Wang, P., Changa, C. M., Watson, M. E., Dick, W. A., Chen, Y., \& Hoitink, H. A. J. (2004). Maturity indices for composted dairy and pig manure. Soil Biology and Biochemistry, 36, 767-776. http://dx.doi.org/10.1016/j.soilbio.2003.12.012

Wong, J. W. C., \& Selvam, A. (2006). Speciation of heavy metals during co-composting of sewage sludge with lime. Chemosphere, 63, 980-986. http://dx.doi.org/10.1016/j.chemosphere.2005.08.045

Wu, D. L., Liu, P., Luo, Y. Z., Tian, G. M., \& Mahmood, Q. (2010). Nitrogen transformation during co-composting of herbal residues, spent mushrooms and sludge. Journal of Zhejiang University Science, B, 1862-1783.

Yamato, M., Okimori, Y., Wibowo, I., Anshori, S., \& Ogawa, M. (2006). Effects of the application of charred bark of Acacia mangium on the yield of maize, cowpea and peanut, and soil chemical properties in South Sumatra, Indonesia. Journal of Soil Science and Plant Nutrition, 52, 489-495. 
http://dx.doi.org/10.1111/j.1747-0765.2006.00065.x

Yeoh, C. Y., Chin, N. L., \& Tan, C. S. (2011). Co-composting of palm oil mill wastes. Journal of Food Agriculture and Environment, 9(3-4), 880-885.

Zhang, Y., \& He, Y. (2006). Co-composting solid swine manure with pine sawdust as organic substrate. Bioresource Technology, 97, 2024-2031. http://dx.doi.org/10.1016/j.biortech.2005.10.004

Zhang, R., Ishibashi, K., \& Day, D. L. (1991). Experimental study of microbial decomposition in liquid swine manure, and generation rates of ammonia. Proc. Livestock Waste Management Conference. ASAE St. Joseph, Michigan.

Zhu, N. (2007). Effect of low initial $\mathrm{C} / \mathrm{N}$ ratio on aerobic composting of swine manure with rice straw. Bioresource Technology, 9, 89-93.

Zorpas, A. A., Constantinides, T., Vlyssides, A. G., Haralambous, I., \& Loizidou, M. (2000). Heavy metal uptake by natural zeolite and metals partitioning in sewage sludge compost. Bioresource Technology, 72, 113-119. http://dx.doi.org/10.1016/S0960-8524(99)00110-8

\section{Copyrights}

Copyright for this article is retained by the author(s), with first publication rights granted to the journal.

This is an open-access article distributed under the terms and conditions of the Creative Commons Attribution license (http://creativecommons.org/licenses/by/3.0/). 